\title{
THE EPIDEMIOLOGY AND CONTROL OF SCHISTOSOMIASIS MANSONI WHERE BIOMPHALARIA TENAGOPHILA IS THE SNAIL HOST*
}

\author{
Luiz Candido de Souza Dias** \\ Carmen M. Glasser*** \\ Arnaldo Etzel*** \\ Urara Kawazoe** \\ Sumie Hoshino-Shimizu**** \\ Hermínia Yohko Kanamura**** \\ José A. Cordeiro** \\ Oswaldo Marçal Júnior** \\ José F. Carvalho** \\ Fernando L. Gonçales Júnior** \\ Rosa Patucci***
}

\begin{abstract}
DIAS, L.C. de et al. The epidemiology and control of schistosomiasis mansoni where Biomphalaria tenagophila is the snail host. Rev. Saúde públ., S. Paulo, 22:462-3, 1988.

ABSTRACT: The epidemiology and control of schistosomiasis mansoni in the Municipality of Pedro de Toledo (State of S. Paulo, Brazil) since 1980, has been studied. In 1980 the prevalence evaluated by stool exams (Kato-Katz method) was $22.8 \%$ and no statistical difference at $5.0 \%$ level was observed between rural and urban zones. The intensity of infection was low (58.5 eggs/g of faeces); the highest prevalence and intensity of infection rates were observed within the group of from 5 to 29 years of age, respectively. The transmission of schistosomiasis usually occurred during leisure time. The majority of the carriers of the parasite were asymptomatic. Of the $B$. tenagophila examined only $0.4 \%$ were found to be infected. The control programme has been intensified from 1981 on resulting in a sharp decrease in the prevalence from $22.8 \%$ in 1980 to $6 \%$ at the present time. This result shows that, in spite of the control programme there is a residual human prevalence. A beginning has been made on the investigation into the possible causes of this residual prevalence $(6.0 \%$ was maintained through out 1987).
\end{abstract}

UNITERMS: Schistosomiasis mansoni, occurrence. Biomphalaria tenagophila. Schistosoma mansoni. Health surveys.

In Brazilian endemic areas of schistosomiasis mansoni the major intermediate host is $B$. glabrata, though there are some places where the vector is $B$. straminea. Areas in which the intermediate host is $B$. tenagophila are more restricted. The present work tries to fill the gap in the knowledge of the natural history of schistosomiasis in areas where the snail is $B$. tenagophila.

The first report on autochthonous schistosomiasis cases in the Pedro de Toledo Municipality(State of São Paulo, Brazil), in the Ribeira River valley region were presented by Piza \& Ramos (1960). The schistosomiasis control programme was introduced in the area by SUCEN (Superintendency of Endemic
Diseases Control), starting in 1970 . Yearly stool exams, chemotherapy of infected patients, application of molluscicide, health education and sanitation were all part of this programme. In spite of this effort the prevalence has increased from $4.0 \%$ in 1970 to $12.0 \%$ in 1978 , in which $85.0 \%$ consisted of autochthonous cases.

We started the present work in 1980 in Pedro de Toledo Municipality. Stool exams (KatoKatz method, three slides per person) were performed for a total of 4,741 individuals. Of these, $22.8 \% \quad(81.0 \%$ autochthonous from Pedro de Toledo) were found infected: the rural population presented a higher infection rate, $25.6 \%$, as compared with the urban population

* Supported by "Superintendência de Controle de Endemias" (SUCEN), "Fundação de Amparo à Pesquisa do Estado de Såo Paulo" (FAPESP). Process n. 87/1683-8, and "Conselho Nacional de Desenvolvimento Cientifico e Tecnológico" (CNPq). Process n. 40.3797/82.

"** "Universidade Estadual de Campinas" (UNICAMP) - Caixa Postal 6109 - 13081 - Campinas, SP - Brasil.

*** "Superintendência de Controle de Endemias" (SUCEN) - Rua Paula Souza, 166 - 01027 - São Paulo, SP - Brasil.

**** Departamento de Análises Clínicas e Toxocológicas da Faculdade de Ciências Farmacêuticas da Universidade de São Paulo - Av. Prof. Lineu Prestes, 580 - 05508 - São Paulo, SP - Brasil. 
rate, $20.2 \%$, but not significant at the $5.0 \%$ level. Infection intensity was low: we found a geometric mean of 58.5 eggs per gram of faeces. According to the age groups, the intensity of infection correlated well $\left(r_{s}=\right.$ 0.745 ) whith the prevalence rates. Of the $B$. tenagophila only $0.4 \%$ were found infected. Comparison of prevalence between sexes in the population through an analysis of variance (ANOVA) showed statistical significance (male infection > female infection). The same technique was employed to compare prevalence among age groups; it can be inferred from the analysis that prevalence is higher for the ages ranging from 5 to 29 years. Age group 10-14, 15-19 and 20-24 years had higher prevalence, compared with the remaining age groups. The transmission of schistosomiasis usually occurs during leisure time and also by the use of water streams for housework in the rural zone. The majority of the carriers of the parasite was asymptomatic. We have never observed severe cases.

Our intensified control programme initiated in 1981 resulted in a sharp decrease in the prevalence rate, from $22.8 \%$ in 1980 to $6 \%$. This low level of prevalence has been maintained through 1987 . This result shows that, in spite of the control programme, there is a residual humam prevalence.

We have just started investigating the possible cases of this residual prevalence, like incidence, parasitological rate cure, morbidity, reinfection, intensity of infection, immunoepidemiology, water-contact patterns, risk factors for the infection, socio-economic situation, sentinel-mice, the role of small mammals, density of $B$. tenagophila, and susceptibility of Schistosoma mansoni to schistosomicidal drugs.

DIAS, L.C. de S. et al. Epidemiologia e controle da esquistossomose mansônica em área onde o hospedeiro intermediário é Biomphalaria tenagophila. Rev. Saúde públ., S. Paulo, 22:462-3, 1988.

RESUMO: Desde 1980, está-se estudando a epidemiologia e o controle da esquistossomose mansônica no Município de Pedro de Toledo (Estado de São Paulo, Brasil). Em 1980 a prevalência avaliada por exame de fezes (método de Kato-Katz) foi de $22,8 \%$. Estatisticamente, ao nivel de $5 \%$, não houve diferença nas prevalências observadas nas zonas rural $\mathbf{e}$ urbana. A intensidade de infeç̧ão foi baixa (média geométrica de 58,5 ovos por grama de fezes). As maiores prevalências e intensidades de infecção foram registradas na faixa etária de 5 a 29 anos. Geralmente a transmissão da endemia verificou-se durante o lazer. Apenas $0,4 \%$ de $B$. tenagophila mostraram-se positivos para cercárias de $S$. mansoni. A maioria dos portadores era assintomático. O programa de controle foi intensificado após avaliação dos dados de 1980 , resultando em diminuição acentuada da prevalência de $22,8 \%$ em 1980 para $6 \%$. Esta prevalência residual vem se mantendo até 1987. Agora iniciamos estudos para investigar as possiveis causas dessa prevalência residual.

UNITERMOS: Esquistossomose mansônica, prevalência. Biomphalaria tenagophila. Schistosoma mansoni. Inquéritos epidemiológicos.

\section{REFERENCES}

1. PIZA, J. de T. \& RAMOS, A. da S. Os focos autóctones de esquistossomose no Estado de São Pauln. $A, q$. Hig., S. Paulo, 25:261-71, 1960.
Received in $11 / 4 / 1988$

Reviewed in $4 / 8 / 1988$

Accepted in $9 / 8 / 1988$ 